Serhii Cherniak,

PhD (Candidate of Pedagogical Sciences), associate professor, senior researcher, Department of Innovations and Strategies of Educational Development, Institute of Education of NAES of Ukraine, 52-D, Sichovykh Striltsiv Str., Kyiv, Ukraine

DOMESTIC AND FOREIGN CONCEPTS OF PERSONAL EDUCATION: THEORETICAL REVIEW

The article deals with leading foreign and domestic concepts of personal education. The conceptual base of the modern foreign pedagogy is represented by the following concepts: dialectical materialist (Marxist), technocratic, authoritarian rationalism, psychoanalytical, pragmatic, neohumanistic, the concept of neothomism. The Marxist pedagogy is based on dialectical materialism. The basis of the technocratic concepts of identity formation is the idea of the possibility of a free external determination of human behavior. The essence of modern technocratic pedagogical theories involves highlighting the issues of external regulation of human behavior by means of developing his/her socially acceptable responses based on carefully developed pedagogical techniques. The defining feature of the formation of a personality according to the theoretical foundations of the concept of personal education of authoritarian rationalism is the formation of ritual behavior model in youth as an indicator of social adaptation. The psychoanalytic concept of education created by the Austrian psychologist Z. Freud was reviewed in the paper as well. Besides, the pragmatic concept of personal education was also considered. The methodological basis of modern neohumanistic concepts of education includes the existentialism, humanistic school of psychology, socio-critical Frankfurt School. Modern philosophical and pedagogical concept of Catholicism, represented by J. Maritain, J. Cunningham, was also described in details. Besides, the leading concepts of personal education in contemporary Ukrainian pedagogy were discussed in the paper as well. They are represented by the system concept, the concept of democratization, system-role concept, the concept of national education, cultural concept, the concept of civic education, self-education, and personality-oriented education concept. The carried out review of the domestic and foreign concepts of personal education proves the plural character of the modern conceptual basis of education. It can be explained by the reconsideration of educational aims with regard to the social factor, which involves the complex dialectical unity of individual and social components of education.

Keywords: pedagogical concepts, personal education, concepts of education, self-education, scientific review.

Подано до редакиії 03.02.2017

Рецензент: д. пед. н. Л. А. Онищукк

UDC: $378.013+418.020 .92$

DOI: https://doi.org/10.24195/2414-4665-2017-2-6

Nataliia Ababilova,

PhD (Candidate of Pedagogical Sciences), associate professor,

Department of Translation,

Mykolaiv V. O. Sukhomlynskyi National University, 24, Nikolska Str., Mykolaiv, Ukraine

\title{
FUTURE TRANSLATORS' TRAINING FOR PROFESSIONAL CAREER IN THE MULTICULTURAL SOCIETY
}

The article deals with the issue of future translators' training for successful fulfilment of professional tasks in the multicultural society as well as with the core components of such training. It has been stated that the ability for multicultural communication and tolerance should be developed during future translators' professional training. The author suggests the ways of improving the process of translators' training aiming at their effective functioning in a multicultural society.

Keywords: translators' training, professional career, multicultural communication, tolerance.

\section{Introduction}

Modern Ukrainian society goes through a period of difficult socio-cultural transformations that affect all aspects of its life. Profound changes in the social, political and economic life have a great influence on the development of the educational system. The specificity of transla- tion as a career is that it serves as a link between multilingual and multicultural representatives [9]. So a translator must help overcome cultural differences and contribute to mutual understanding between the subjects of intercultural communication [10]. The specialists of this field are required to be able to adapt to changing situations, to see 
the difficulties that arise in the real world and find their own ways of overcoming them; to be sociable, to contact various social groups, to cooperate with other specialists in various fields of knowledge, preventing conflict situations or avoiding them skillfully; to work on the development of their own cultural level; to effectively establish cultural ties.

The aim of the article is to analyze the qualities necessary for the successful translators' performance of their professional duties in a multicultural society and propose the ways contributing to the improvement of translators' training under the conditions of such a community.

\section{Discussion}

Three types of relationships between cultures are known to exist: utilitarian attitude; opposition of one culture to another and interaction of cultures or mutual enrichment [4]. Of course, it is unacceptable to cultivate the first two types in the process of future translators' training, since they do not contribute to establishing the friendly relations between representatives of different cultures. From the point of view future translators' professional characteristics and training, the last type of relationships makes it possible to develop socio-cultural awareness and readiness for interpersonal and international communication.

Taking into account the fact that "intercultural communication" is defined as a "set of various forms of relationship and communication between individuals and groups belonging to different cultures" [2: 142]; "exchange of knowledge, ideas, thoughts, concepts and emotions between people of different cultures" [5: 295] we can conclude that the ability to implement intercultural communication is not identified only with the knowledge of the language, as the national specific features of the various components of cultures may complicate the process of such communication. These include: traditions, customs and ceremonies; consumer culture; everyday behavior; national set of mind; art culture, reflecting the cultural traditions of a particular ethnic group. It is "the lack of linguistic and sociological and cultural knowledge of a foreign language society in the process of translation that can lead to social and ethnic barriers" [1:86-87].

Speaking about intercultural communication it is worth mentioning that the participants of communication differ not only in verbal but non-verbal communication (information which underlines or emphasizes what is expressed verbally). Such statements are based on Allan Pease's research where it is stated that only $7 \%$ of information is conveyed verbally, $38 \%$ is passed by means of tone and intonation and $55 \%$ of information is transmitted through facial expressions, gestures and posture. The researcher states, that in cases when the verbally conveyed information does not coincide with that conveyed non-verbally, it is preferable to trust facial expressions and gestures as they are subject to the subconscious, and thus they show exactly what is meant [7]. Hence, the interpretation of nonverbal behavior is capable to facilitate intercultural communication and help avoid unneces- sary difficulties. Knowledge about the sources of cultural differences and factors that may contribute to the successful intercultural dialogue, understanding the impact of culture on the process of dialogue, promotes future translators' success and competitiveness. In our view, teaching the ability to implement intercultural communication in the process of future translators' training allows them to effectively interact with people of different cultures that will encourage mutual understanding. It should be noted that we are speaking about translators' ability to decipher and interpret nonverbal signs, but not to use them during the process of translation, since the use of gestures and facial expressions is not permissible in the performance of translators' tasks $[6 ; 12]$.

The success of a specialist in intercultural relations characterizes him/her as an individual open to new information, ready to accept another person as a representative of a foreign language culture. He/she respects other people's customs and traditions, is able to relate to the communication partner, imagine his/her mindset. In addition, a specialist knows the history, especially the mentality of different nations, he/she is familiar with the political situation not only in his/her own country, but also other countries, which allows him/her to step outside of his/her culture, to acquire the qualities needed for the mediation mission, but without losing his/her own cultural identity. To our mind only such a specialist will be able to carry on an intercultural dialogue which is one of the key concepts of international politics. Such a dialogue is considered to be the basis for the application of the values of cultural diversity in everyday life, a tool for using opportunities, which are caused by the presence of a wide variety of cultures.

Speaking on the implementation of cross-cultural communication we cannot but mention the emergence of inter-cultural, inter-ethnic scuffles, which may be avoided on condition of tolerant attitude towards other nations and other systems of values and manners. It should be said that the divergence of interests in the process of communication gives rise to such conflicts, implying a degree of aggression and can adversely affect the course of communication. A translator should be tolerant to other beliefs and traditions, as the difference in the sets of minds, low spirituality, and ignorance of cultural events can contribute to confrontations.

From our point of view, a translator should be sociocultural tolerant to others regardless of their ethnic, national or cultural identity, to another kind of attitudes, habits, with respect to the characteristics of different cultural groups or their representatives. D. Zinoviev suggests that this kind of tolerance reflects the confidence and awareness of people's safety position; it is a sign of an open to all ideological currents person, who is not afraid of comparison with other people's points of view and does not avoid spiritual competition. The socio-cultural tolerance reflects the individual's desire to achieve mutual respect, understanding and reconciliation of diverse interests and minds mainly by using explanation and persuasion techniques [3]. So, socio-cultural and intercultural 
tolerance can be considered as an indicator of the absence of the nationalistic manifestations, and group, age and social discrimination. It provides successful socialization. A tolerant translator is self-possessed, has the ability to control his/her feelings and emotions, which helps to assess the situation and adjust his/her actions and deeds, the ability to achieve mutual respect, understanding and reconciliation of different interests and points of view without pressure.

Based on the foregoing, we have assumed that it must be appropriate to train interpreters for their successful professional activities in the multicultural society by the methods of case studies, projects, role plays and exercises, which have been widely used while teaching such subjects as "Practical course of English', "Country Studies" and the developed special course "Competitiveness of future translators", which has been included in the curriculum of future translators' training at Mykolaiv V. O. Sukhomlynskyi National University. And further we are going to focus on the detailed description of the methods used in the process of teaching of the designed special course.

We have chosen the case study method "Separation of a situation that organizes students on the problem formulation and searching for options to solve it" [8: 30]. It creates interest and positive motivation, provides engaging students in the learning process, and promotes their professionalism. This method lets effectively combine the knowledge acquired from various courses and experience, and some acquired skills, use them in an integrated matter and develop social mobility, as students see themselves as participants in simulated professional situations that encourage them to tackle sudden and unexpected problems that have arisen and present innovative solutions that shape their ability to improvise. Students' work on case studies involves five stages (by A. Dolhorukov). During the first stage the students were acquainted with the situation and its features. Singling out the basic problem, the factors that may affect its solution was the second stage. The next step was to offer concepts and themes for "brainstorming". Analysis of the effects of the adoption of a decision was carried out at the fourth stage. The proposal of options (sequential action), naming of potential problems, mechanisms of prevention and resolution were done during the fifth stage.

Practical cases from everyday life and scientific literature were used in the abovementioned special course. Thus, one of the cases reflected the real situation that students encountered during their practice. During the negotiations the head of the company was behaving rather impolitely concerning the representative of another country, he started the conversation with a taboo topic. When the translator tried to explain the differences in cultures, the head of the company said that a foreigner came to his country, so he should behave politely, and he (the boss) is at home and does not have to adapt to others and reflect on their behavior. Consequently, the students were asked to comment on the situation that had arisen, the possible behavior of the interpreter and his own thoughts on this problem. While working on the cases the students had the opportunity to improve their foreign language (reading, speaking and listening skills) as the cases were given in English; to learn how to deal with unique and unusual situations that could happen in real life and on which the fate of the enterprise, organization or company may depend on. The case study method promoted active learning and practical knowledge acquisition as certain practical information may be more useful in work than theoretical knowledge. In addition, the students formed skills of improvisation that may be useful for them in the future, and the ability of the translator to implement intercultural communication (the ability to understand the importance of non-verbal information), tolerance to those expressing their points of view.

Students' translation practice has become not only the source of cases but also of role-playing games that resembled real situations that may occur during translation. Role-playing games were usually held on the teacher's guidance and the participants were performing various roles. It is interesting to note that after doing translation internship the students themselves suggested some role-playing games. Thus, "A translator and foreign tourists" is an example of such a game. The roleplaying involved several stages. At the preparatory stage the topic was announced, the plot, the tasks were stated and the description of the roles was given. During the game the students had to adapt their roles to the proposed situations. In some games the students represented themselves while in others the roles were imaginary and so the students had to adjust to the proposed parts. According to the named game the students did not know beforehand the question to be asked, so to fulfil the task and to achieve the aim they had to show ingenuity and quick response when answering. Moreover, they were to follow the verbal and non-verbal communication, be tolerant while dealing with the "foreigner", and overcome difficulties arising in the course of translation.

It is known that the implementation of research projects in teaching foreign languages creates favorable conditions for the formation of the capacity for intercultural communication and education [11]. International relations experts are of two opposing views on the degree of taking into account national circumstances in the conduct of public affairs. Thus, some believe that the globalization of information systems, the development of international political, economic and cultural ties promote mutual penetration of national styles of communication, form identical criteria for negotiations. Others, however, tend to single out the peculiarities of national importance, as they can cause problems during negotiations between representatives of different cultures. Taking this information into account while teaching the course "Country studies" we offered the students to make some projects one of which was "National characteristics of communication". The following tasks have been set: 
- educative: students have learnt to create projects that reflect personal and collective goals of team members; to improve skills in text, graphics, and other tools in order to make a project; to develop the ability to work in the operating system Windows and systematize theoretical knowledge;

- training: to improve the ability to implement intercultural communication, learn to organize their own work, to coordinate it with the work of the group, the ability to reasonably defend their point of view and tolerate the opinions of others, to be able to adapt quickly to the conditions encountered unexpectedly, the ability to speak to the classmates with their proposals, "present" themselves and their activities, improve the ability to select and organize information;

- educational: to form respectful and considerate behavior towards the people and team members; be responsible for the team and its members; to form skills to debate, educate respect for the competitors.

The students were divided into groups of three and had to choose three countries (one of which was to be Ukraine, a second one was to be some Asian country and a third one - some European country); they were interested in terms of knowledge / ignorance of cultural traditions, peculiarities of communication with representatives of these states. Thus, each student had the opportunity to familiarize himself/herself with the country he/she was most interested in. The participants had to coordinate their actions in order to accomplish a common project. We should mention that students often chose the eastern countries, which may be explained by the fact that 1) at school much attention is paid to the USA, Britain, New Zealand, Australia and 2) nowadays students lack knowledge about national characteristics of Eastern countries as Ukrainian relationships with them are developing. We had the requirement not to choose one and the same foreign countries by all the groups. While making the project the students had an opportunity to review the specifics of business affairs with representatives of nine countries that was undoubtedly positive, because in this way, they had an opportunity to expand their horizons. The method contributed to the future translators' training aimed at working in a multicultural society because they should find out the features of verbal and nonverbal behavior of people from these countries, their views on clothes during business meetings, leisure, recreation, attitude to favors, distance in communicating, topics that can be discussed during the first meeting.

Therefore, the proposed theme of the project was related not only to theoretical issues, but also practical ones, relevant to everyday life and at the same time required the

\section{REFERENCES}

1. Alekseeva, I. S. (2004). Professionalnyy trening perevodchika: uchebnoe posobie po ustnomu i pismennomu perevodu dlya perevodchikov $i$ prepodavateley [Translators' professional training: study guide in oral integration of knowledge. To perform the project in a proper way the students had to surf the Internet, read various textbooks, get access to electronic libraries to find the appropriate information. It should be noted that some students had the opportunity to communicate in chats with their peers from other countries, which had a positive impact not only on making the project, but also on improving the knowledge of a foreign language. The students affirmed the idea that the intensity of business communication leads to a blurring of national boundaries. Representatives of the Eastern countries are increasingly taking behaviors of their Western partners. Not only similarities but also a lot of differences in the nature of communication of various countries have been stated. It was noted that unlike the Americans, who at first call a person's name and then his surname, the Chinese call the last name and only then the first name of the person. The list of topics to be discussed at the meetings with partners was compiled. Thus, the students came to know that the most popular topic of conversation with the Australians is sport, while the Italians like talking about culture. Some nations (for example, China) prefer informal conversation, during which they talk about family, children, age and preferences. Vice versa, representatives of Arab countries may be offended by being asked about their wives' health. As for the features of verbal behavior that have been found out and included into the project, the students noted that in some countries (Arab countries, Japan) etiquette forbids to be categorical so during business negotiations one cannot expect to get from the partner such answers as "yes" / "no". If one wants to refuse he/she should do it covertly and diplomatically. It is doubtless that the work provided the students with the information necessary for the successful performance in a multicultural community as knowledge of national characteristics of communication helps to prevent conflicts and social balance breach.

\section{Conclusions}

The internationalization of professional life and economic globalization have set up completely new requirements for translators' training. The need to work for joint ventures or multinational concerns, international projects requires knowing the processes of intercultural communication and being able to solve problems in the field of multicultural relationships. It should be noted that not only the knowledge of grammar terminology or foreign language is important, but also the knowledge of basic differences in communicative behavior, including various forms of addressing, the formulation of speech acts, such as criticism, guidance and request, different strategies of conducting a conversation.

and written translation for translators and teachers]. Saint Petersburg: Izdatelstvo «Soyuz» [in Russian].

2. Grushevitskaya, G. I., Popkov, V. D. (2003). Osnovy mezhkulturnoy kommunikatsii: uchebnik dlya stud. vyssh. ucheb. zavedeniy [Basis of intercultural communi- 
cation: textbook for university students]. Moscow: YuNITI-DANA [in Russian].

3. Zinovev, D. V. (1998). Sotsiokulturnaya tolerantnost - ee sushchnostnye kharakteristiki [Socio-cultural tolerance and its features]. Paradigma - Paradigm, 1, 5061 [in Russian].

4. Krupnov, V. N. (1982). Perevod kak professionalnaya deyatelnost i ego vzaimodeystvie s vidami rechevoy deyatelnosti [Translation as professional career and its connection with other language activities]. Teoreticheskie $i$ eksperimentalnye issledovaniya $v$ oblasti obucheniya rechi i chteniyu: sb. nauchn. tr. MGPIIYa im. M. Toreza - Theoretical and experimental studies in the field of teaching speaking and reading: collection of scientific works of Minsk State Pedagogical Institute of Foreign Languages, 200, 222-234 [in Russian].

5. Matsumoto, D. (2002). Psikhologiya i kultura [Psychology and culture]. Saint Petersburg: proymEVROZNAK [in Russian].

6. Miram, G. E. (2004). Professiya: perevodchik [Profession: translator]. $3^{\text {rd }}$ ed. Kiev: Elga, Nika-Tsentr [in Russian].

\section{ЛІТЕРАТУРА}

1. Алексеева И. С. Профессиональный тренинг переводчика: Учебное пособие по устному и письменному переводу для переводчиков и преподавателей / И. С. Алексеева. - СПб. : Издательство «Союз», 2004. -288 c

2. Грушевицкая Г. И. Основы межкультурной коммуникации : [учебник для студ. высш. учеб. заведений] / Г. И. Грушевицкая, В. Д. Попков. - М. : ЮНИТИ-ДАНА, 2003. - 325 с.

3. Зиновьев Д. В. Социокультурная толерантность - ее сущностные характеристики / Д. В. Зиновьев // Парадигма. - 1998. - № 1. - С. 50-61.

4. Крупнов В. Н. Перевод как профессиональная деятельность и его взаимодействие с видами речевой деятельности / В. Н. Крупнов // Теоретические и экспериментальные исследования в области обучения речи и чтению : сб. научн. тр. МГПИИЯ им. М. Тореза. - М., 1082. - Вып. 200. - С. 222-234.

5. Мацумото Д. Психология и культура / Дэвид Мацумото. - СПб. : пройм-ЕВРОЗНАК, 2002. - 416 с.

7. Piz, A. (2010). Yazyk zhestov [The language of gestures]. A. Piz (trans). Voronezh: Eksmo [in Russian].

8. Frolov, A. G., Khomochkina, S. A., Matushanskiy, G. U. (2006). Adaptatsiya prepodavatelya k professionalno-pedagogicheskoy deyatelnosti v vysshey shkole [Teachers' adaptation to professional activity at universities]. Educational Technology \& Society, 9(2), 265-276 [in Russian].

9. Khaleeva, I. I. (1989). Osnovy teorii obucheniya ponimaniyu inoyazychnoy rechi (podgotovka perevodchikov) [Basis of the theory of teaching foreign language understanding (training or translators)]. Moscow: Vysshaya shkola [in Russian].

10. Shveytser, A. D. (1988). Teoriya perevoda: Status, problemy, aspekty [Theory of translation: status, problems, aspects]. Moscow: Nauka [in Russian].

11. Byram, M., Morgan C. (1994). Teaching and learning language and culture. Clevedon, Philadelphia, Adelaide. Multicultural Matters Ltd., [in English].

12. Schutz, A. (1998). Assertive, offensive, protective, and defensive styles of self-presentation: a taxonomy. The Journal of psychology, 132 (6) [in English].

6. Мирам Г.Э. Профессия: переводчик / Г. Э. Мирам. - К. : Эльга, Ника-Центр, 2004. - 3-е изд. $-160 \mathrm{c}$

7. Пиз А. Язык жестов / [А. Пиз пер. с англ.]. - Воронеж : Эксмо, 2010. - 464 с.

8. Фролов А. Г. Адаптация преподавателя к профессионально-педагогической деятельности в высшей школе / А. Г.Фролов, С. А. Хомочкина, Г. У. Матушанский // Educational Technology \& Society 9(2) 2006. - C. 265-276.

9. Халеева И. И. Основы теории обучения пониманию иноязычной речи (подготовка переводчиков) / И. И.Халеева. - М. : Высшая школа, 1989. - 238 с.

10. Швейцер А. Д. Теория перевода : Статус, проблемы, аспекты. - М. : Наука, 1988. - 214 с.

11. Byram M., Morgan C. Teaching and learning language and culture. - Clevedon, Philadelphia, Adelaide. Multicultural Matters Ltd., 1994. -219 p.

12. Schutz A. Assertive, offensive, protective, and defensive styles of self-presentation: a taxonomy // The Journal of psychology, 132 (6), 1998.

Наталія Миколаӥвна Абабілова, кандидат педагогічних наук, доцент кафедри перекладознавства, Миколаївського національного університету імені В. О. Схомлинського, вул. Нікольська, 24, м. Миколаїв, Украӥна

\section{ПІДГОТОВКА МАЙБУТНІХ ПЕРЕКЛАДАЧІВ ДО ПРОФЕСІЙНОӤ ДІЯЛЬНОСТІ В УМОВАХ ПОЛІКУЛЬТУРНОГО СУСПІЛЬСТВА}

Сучасне українське суспільство наразі переживає період складних соціально-культурних перетворень, які торкаються всіх аспектів життя. Кардинальні зміни в соціальному, політичному та економічному житті впливають на розвиток системи освіти. Специфіка перекладацької діяльності полягає в тому, щоб забезпечити взаємодію між представниками різних культур. Мета статті - проаналізувати якості, необхідні для успішного виконання перекладачами їхніх професійних обов'язків у полікультурному суспільстві і запропонувати шляхи, 
які сприяють поліпшенню підготовки перекладачів в умовах такої спільноти. На сучасному етапі розвитку суспільства до фахівців з перекладу висуваються такі вимоги: можливість адаптуватися до мінливих ситуацій, бачити труднощі, які виникають у реальному світі, та знаходити шляхи їх подолання; толерантність, уникнення та запобігання конфліктних ситуацій; розвиток культурного рівня; встановлення культурних зав'язків. Автор наголошує, що однією з важливих якостей є здатність до здійснення міжкультурної комунікації: як вербальної, так й невербальної. В роботі здатність до здійснення невербальної комунікації розуміється як спроможність інтерпретувати, а не використовувати міміку, жести власне перекладачем. Для успішного виконання професійних завдань у полікультурному суспільстві перекладачеві необхідно бути толерантним, оскільки такий фахівець має можливість контролювати свої почуття і емоції, що дозволяє оцінити ситуацію, свої дії та вчинки; вміння досягти взаємної поваги, розуміння і примирення різних інтересів і точок зору без тиску, а значить він може уникнути міжкультурних та міжетнічних сутичок. Розглянуто умови підготовки перекладачів до успішного функціонування у полікультурному суспільстві на основі використання методу кейсів, проектів, рольових ігор в процесі викладання таких дисциплін, як «Практичний курс англійської мови», «Країнознавство» та розробленого автором спеціального курсу «Конкурентоздатність майбутніх перекладачів», який включено до навчального плану підготовки майбутніх перекладачів в Миколаївському національному університеті імені В. О. Сухомлинського. Наведено приклади проектів, кейсів та ігор, що були апробовані на практиці. Встановлено, що ці методи дозволили сформувати зазначені якості, розширити світогляд студентів, ознайомити їх з можливими труднощами під час виконання професійних обов'язків та шляхами їх подолання.

Ключові слова: підготовка перекладачів, професійна діяльність, мультикультурна комунікація, толерантність.

Submitted on February, 6, 2017

Reviewed by Doctor of Pedagogy, prof. I. Buzhyna

УДК: 376.64-058,6:37(09)"19

Orcid.org / 0000-0003-1841-882X

DOI: https://doi.org/10.24195/2414-4665-2017-2-7

\author{
Ореста Свгенівна Карпенко, \\ кандидат педагогічних наук, дочент кафедри \\ загальної педагогіки та дошкільної освіти, \\ Дрогобииький державний педагогічний університет імені Івана Франка, \\ вул. Франка, 24, м. Дрогобич, Україна
}

\title{
ОРГАНІЗАЦІЙНО-ПЕДАГОГІЧНІ ЗАСАДИ ОПІКИ НАД ДІТЬМИ В ГАЛИЧИНІ (1900-1939 рр.)
}

У статті висвітлено еволюиію організаційних форм надання опіки українській дитині у Галичині. Розкрито діяльність сиротинських рад (громадської, парафіяльної), товариства «Шкільна поміч» (1910), Украӥнського Крайового Товариства охорони дітей і опіки над молоддю (1917). Акцентовано увагу на організаиії опіки над немовлятами, дітьми дошкільного й шкільного віку, сиротами, морально-релігійному вихованні, задоволенні життєво необхідних потреб, матеріальній опіиі. 3'ясовано, щуо зусилля педагогів сконцентровані на виявленні дітей, які потребують опіки, аналізі причин занедбаності дітей, застосуванні відповідних засобів допомоги, створенні бурс, захоронок, сиротинських гнізд.

Ключові слова: опіка, сиротинська рада, «Шкільна поміч», діти-сироти, безпритульні діти, Галичина.

Постановка проблеми. Опіка над дітьми упродовж віків була одним із провідних завдань українців і знаходила втілення у теорії та практиці опікунської діяльності, українській педагогіці. Опіка є предметом зацікавлення різних галузей наукових дисциплін [7]. Сучасні проблеми економічної і суспільно-політичної кризи, вимушене безробіття, виїзд за кордон з метою пошуку роботи, низький рівень заробітної плати спричинили низку нерозв'язаних соціальних проблем, збільшення чисельності сиріт, безпритульних і зубожілих дітей. Подолання означених проблем, удоско- налення змісту опікунської діяльності вимагають об'єднання зусиль різних інституцій, вивчення й осмислення історико-педагогічного досвіду.

Аналіз останніх досліджень і публікацій. 3 початком XXI ст. активізуються історико-педагогічні дослідження, присвячені проблемам національного виховання, теорії і практики опіки громадських, культурно-просвітницьких товариств та організацій у різний період розвитку українського суспільства (Т. Завгородня, Р. Волянюк, І. Курляк, Б. Ступарик, М. Стельмахович, М. Чепіль). 